\title{
The humanistic study of religions: An obscure tradition illuminated by the 'Knights of Labor'
}

\author{
STEFAN ARVIDSSON \\ Linnæus University
}

\begin{abstract}
Today 'humanistic' and 'humanities' are terms rarely used in discussions on methodology and epistemology within the study/history of religions. This article laments this state of affair and reminds the readers of same basic advantages of a humanistic study of religions in comparison to chiefly social scientific approaches to religion and culture. After an initial philosophical argument on the implications of 'humanistic', the article touches upon the significance of historical failures, utopianism, empathy and 'the orectic'. These discussions take place against an analysis of the mythology and ritual life of the 19th century, American, socialist order The Knight of Labor.
\end{abstract}

Keywords: humanistic, humanities, methodology, epistemology

For more than a century 'humanistic', and related words, maintained a central position in the scholarly and cultural life of the Western world. They were used to organise universities, to form the basis of educational policy, and to add force to arguments in cultural discourse. Today, however, these words languish within all sectors of society, including the academic study of religions. ${ }^{1}$ Traditional humanistic fields of research and methodologies such as philology, semiotics, iconography, phenomenology, literary analysis, folkloristics, hermeneutics, and even historiographical reflection are losing ground within the study of religions. Instead, at least since the mid-twentieth century, social-scientific perspectives have been emerging as the dominant force and during the last two decades natural-scientific approaches, moreover, have been gaining ground. In this article I wish to remind the reader of what the humanistic study of religions is all about. I will do this with the help of some general philosophical reasoning and with material concerning a secret Christian and socialist fraternity. At the outset I would like to make clear that I consider 'the humanistic study of

1 For the Swedish discussion of 'the crisis in the humanities', see Nordin 2008, Ekström \& Sörlin 2012, and Forser \& Karlsohn 2013. To a certain extent, the Swedish discussion is a reflection of the Anglo-Saxon debate: see Nussbaum 2010, Small 2013, and Belfiore \& Upchurch 2013 
religion' to be synonymous with 'the history of religions', except that in this context the former expression better emphasises the aspects that concern the philosophy of science. Consequently, I hope it will be clear that my overall standpoint has very little to do with what historian of religions Russell $\mathrm{T}$. McCutcheon, in a polemical article, has labelled 'the liberal humanistic study of religion $(2006,726)^{\prime}$.

\section{The characteristics of the humanities}

What characterises humanistic scholarship? Discussion concerning the features of the humanities can be traced at least to debates around the turn of the twentieth century, when neo-Kantian philosophers set out to determine the difference between natural science and what they called Geisteswissenschaft, 'spiritual science' (Persson 1994, p. 164ff). Geisteswissenschaft was how the discipline we know today as the humanities was designated, but it was above all, in typical nineteenth century fashion, history/historiography that acted as the prototype for Geisteswissenschaft. However, the aim of this article is not to examine the relationship between the natural sciences and the humanities, even if that issue is relevant when the impact of cognitive science and evolutionary theories on the study of religions during the last two decades is considered. Instead, I wish to discuss the relationship between the humanities and the social sciences, which still was an emerging tradition when the neo-Kantians demarcated the principal different scientific/ scholarly traditions, but which without doubt would have been considered part of Geisteswissenschaft. The similarities between the humanities and the social sciences, which the longstanding appropriation of each other's methods, theories, and concepts demonstrates, are obvious. However, as is more often forgotten, the differences between them are also crucial.

The first step in differentiating the humanities from the social sciences, which I primarily refer to here as disciplines such as sociology, anthropology, psychology, and political science, is to demonstrate that the cultural and social dimensions of human life do not entirely overlap. To study humanity as a social being is not quite the same as to study man as a cultural being. The cultural dimension transcends the social, both in terms of what is 'beneath' and what is 'above' the social dimension in a person's life: beneath the social being exists nature, and above, 'spirit', creativity, the 'not-yet-conscious' (Bloch's 'Noch-Nicht-Bewusste'), and historical change. How does this transcending function? Concerning encounters with nature we should first note, in marked contrast to fashionable social constructivism, 
that individuals do have a relationship with nature (including their own body) that is partially independent of social prefigurations. For example, we find no social construction of 'the terrible pain of gallstones'. Nor does there exist a social construction of 'the experience of orgasm', despite the extreme exposure of sexual behaviour in our contemporary culture. Our experiences of the body are indeed moulded by society; however, they are only moulded to a certain extent. In The Idea of Culture (2000) the Marxist literary theorist Terry Eagleton notes that if you give a child a light slap for a misdemeanour the child will certainly cry, whereas you can take part in a robust game and strike the child much harder and they will only laugh happily. Body experience is thus, as social constructivists rightly argue, a social construction. However, if you hit the child really hard they will probably start to cry, even though it was done during a game. Eagleton explains:

Meanings can mould physical responses, but they are constrained by them too. The adrenal glands of the poor are often larger than those of the rich, since the poor suffer more stress, but poverty is not able to create adrenal glands where none exist. Such is the dialectic of nature and culture (Eagleton 2000, 87).

It is not difficult to find similar examples: the fact that we can enjoy the view of wild, magnificent nature depends, of course, on a certain strain of romanticism developed by the victorious bourgeoisie, which, in turn, is linked to certain technological advances, industrialisation, urbanisation, and so on. But the character of the experience of nature - the sensation of cruising down a ski slope on sparkling snow or watching the sunset in the Yosemite valley - cannot be captured through knowledge of these historical developments. Humanistic research must therefore always contain an element of phenomenological description and analysis. A description of an experience alone can certainly never constitute a complete study, but a vivid, detailed, and sensitive description that gives the reader a sense, for example, of what it is to confront nature not as a blasé metropolitan but as a toiling Nepalese farmer, is a sine qua non for the humanities. ${ }^{2}$ Phenomenol-

2 Windelband has a rather extreme view of the nature of the historian's task: 'Für den historiker besteht die Aufgabe, irgend ein Gebilde der Vergangenheit in seiner ganzen individuellen Ausprägung zu ideeller Gegenwärtigkeit neu zu bleiben. Er hat an Demjenigen was wirklich war, eine ähnliche Aufgabe zu erfüllen, wie der Künstler an Demjenigen was in seiner Phantasie ist. Darin wurzelt die Verwandschaft des historischen Schaffens mit den ästhetichen, und die der historischen Disziplinen, mit den belles lettres. Hieraus folgt, daß in dem naturwissenschaftlichen Denken die Neignung zur Abstraktion verwiegt, in dem historischen dagegen diejenige zur Anschaulichkeit.' $(1907,369)$ For a study that has carried the thick descriptive virtues to its extreme, see the 1237-page dissertation by Barnekow (2003) on his 'experience of Zen'. 
ogy, in this very basic sense, is a method we cannot abandon because of the well-known methodological shortcomings of the past.

Besides encounters with nature and their own bodies human beings engage in activities that should be characterised as asocial. These encompass daydreaming, contemplation and meditation. They can also involve masturbation, murder, or suicide. Admittedly, these phenomena (many of great religious importance in many traditions) do not occur in a social vacuum, but are only rarely the result of social ethics and edicts. They do not favour, at least not directly, the social reproduction of society. It would be stretching the concept 'social' too far to claim, for example, that suicide is a social act. ${ }^{3}$

Another human phenomenon that in no direct way favours social reproduction is art in its broadest sense, an activity that is very much an object of humanistic studies. Of course, poetic representations of heroism, for example, have throughout history served as a means to manipulate the self-image of young men, but art has also transcended the social commandments. Even if art has often been part of the official ideology of its time, it must be emphasised that it is not a cog that easily interlocks with the other wheels of the social machinery. The transcendence of art may relate both to innovative forms and motifs and to its social content. There is certainly a discipline called the sociology of culture that explores the links between society and art, but for humanists it is just as important to study the fact that art, even religious art (for example the unique and innovative baroque paintings of Caravaggio, interlocked as they were with the Counter-Reformation) sometimes transcends the cultural limits of its time. The existentialist philosopher Jean-Paul Sartre criticised 'vulgar' materialists who reduced art to social class: 'Valéry is a petit bourgeois intellectual, no doubt about it. But not every petit bourgeois intellectual is Valéry $(1976,56)$.' If human life could be captured in the form of 'social construction', transcendence would be impossible. There are always, however, cracks in society and the ideological apparatus in which change germinates: if those cracks did not exist, historical change would in principle be impossible. It is precisely for this reason that historical studies occupy a crucial role in humanistic research.

3 Durkheim's famous analysis of suicide in Le Suicide (1897) is the obvious argument for suicide as a 'social fact', but even here one must - in addition to noting the prevalence of suicide as a result of 'asocialisation' (suicide égoïste and suicide anomique) - emphasise the importance of distinguishing between, on the one hand, the social frameworks and, on the other, the phenomenon itself as well as its logic and consequences. While suicide in general is an effect of social factors, it is rarely (perhaps with martyrs, a kind of suicide altruiste, as an exception) in itself a cog in the social machinery. 
But the humanities have an even bigger issue than historical change on their agenda. When we no longer confine ourselves to questions about the character of a certain people in a certain historical era, but rather discuss what the ancient Romans have in common with Genghis Khan's Mongols, we reach the core of the humanities: the big question of human nature. (This profound wondering is the reason why philosophy is part of the humanities.) And here, a good distance from the social sciences, the humanities actually meet the natural sciences. It is on the fence that separates the humanities from the natural sciences that the questions of human nature and historical change are perched. This is where we need to be careful of the dialectic between what is essential and general, and what is historically and individually specific. To understand humanity we must - as dialectical materialism once emphasised - at the same time understand both the form of the human being realised in a given society and the potential human being. The sybaritic, cyboric, and computer-bound Westerner of the twenty-first century could not be anticipated by those who observed their struggling and exhausted fellow human beings in the fourteenth, but today we know that such a cultural existence must have had the potential to exist then.

After this general introduction I would like to highlight a number of significant humanistic themes. Of the five themes I will discuss, two or three are commonplace. Out of a growing frustration with students and colleagues who manifest suspicions about the interpretation of cultural phenomena in general, and instead opt for social scientific methods, I believe nevertheless that these are worth being reminded of.

\section{A rambling history}

When the neo-Kantian philosophers established the difference between natural science and Geisteswissenschaft, they claimed that while natural science searched for regular laws, Geisteswissenschaft concerned itself with what is unique and particular. History, according to Wilhelm Windelband in his seminal speech of 1894, involves 'a loving adornment of the specific' (liebevollen Ausprägung des Besonderen; 1907, 368). This statement is both misleading and wise. It is misleading because scholars within the humanities do use statistical surveys and implement studies of the normal and typical. The members of the Annales School, among others, proved a long time ago the usefulness, indeed indispensability, of statistics and demography in historical research. What is wise about the ideas of Windelband and the neo-Kantians is that they are correct in claiming that - and this is where the 
line is drawn between the human and social sciences rather than between natural science and Geisteswissenschaft - the humanities have the privilege of caring for the statistically unusual, the unique, the bizarre, and the ingenious. The motivation for this privilege is simply that such phenomena, however socially insignificant they may be, play a part in the history of humanity. ${ }^{4}$

Let me exemplify the relevance for the humanities of what is not considered mainstream, or what did not prove to be historically successful, with a short description of an American Christian and, at the same time, socialist fraternity influenced by freemasonry.

In the wake of the American Civil War and in the face of the failures of the first trade unions The Noble and Holy Order of the Knights of Labor (abbreviated to the $\mathrm{K}$ of $\mathrm{L}$ ) was secretly inaugurated on 28th December 1869. Outside the circle of oath-bound participants the fraternity was symbolised with five asterisks, ${ }^{\prime * * * * *} .{ }^{5}$ The stated purpose was to tame ' $[\mathrm{t}]$ he alarming development and aggressiveness of great capitalists and corporations (in 'Record' 1878, 28)'. This purpose was not unique to the K of L, no more than was the idea of fashioning a secret brotherhood. The fact is that the period from the mid-1800s to the 1880s was a period of blossoming secret orders and workers' friendly societies. Occult rituals, secret handshakes, and ancient mysteries were straws many workers clutched in the wake of the defeat of the first trade unions. What made the $\mathrm{K}$ of $\mathrm{L}$ unique is therefore not so easy to detect, but it was the first fraternity that welcomed all wage labourers, regardless of skill, gender, or race. Historian Norman J. Ware writes in his pioneering work 'The Labor Movement in the United States 1860-1895. A Study in Democracy' (1929):

Emphasis on the principle of solidarity is the beginning of understanding of the Knights of Labor. Strange and grandiose names and titles, rituals, secrecy, forms of organization, even activities, were secondary. The Order tried to teach the American wage-earner that he was a wage-earner first and

4 There is, however, a risk - that has often occurred throughout the history of religions - that the hermits, the holy fools, the founders of religion, strange cults and the like, are surrounded by a romantic shimmer and therefore attract too much research at the expense of statistically normal religion. The scholarly community must come to their senses here and balance themselves between spending time and resources on the normal, which may be trivial, and the fascinating, which can be obscure.

5 In the earliest draft of what would become Adelphon Kruptos ('Agenda. In arcana'), written by the first Grand Master Workman, Uriah Stephens, the brotherhood is mentioned as 'the noble and Holy Order of Peace' and as 'A'. The latter seems to be an acronym for 'archeon' and probably refers to the Greek word archeion, a government building, 'archive'. In 'Record of proceedings of the General Assembly of the ${ }^{* * * * * * * * *}$ held at Reading, Pennsylvania January $1-41878^{\prime}$ the brotherhood was encrypted with apparently no less than nine asterisks. 
a bricklayer, carpenter, miner, shoemaker, after; that he was a wage-earner first and a Catholic, Protestant, Jew, white, black, Democrat, Republican, after (Ware 1959, xviii).

With time these qualities made the $\mathrm{K}$ of $\mathrm{L}$, under the leadership of Terence V. Powderly, 'the first American working-class hero of national stature (Phelan 2000, 1)', grow into an extremely influential organisation for class struggle.

The K of L wanted to fight tyrants and others who danced around the golden calf. They saw themselves embroiled in a holy war: 'We'll fight in this great holy war till we die (quoted in Weir 1996, 117). ${ }^{6}$ Despite the occasionally martial symbolism, the initiated in general cared for a serene and gentle interpretation of knighthood. In his memoirs Powderly recollects that the $\mathrm{K}$ of $\mathrm{L}$ was occasionally compared to the crusaders. This did not fall on fertile ground: 'I can't think of anything more idiotic than a crusader going to rescue the tomb of One who everywhere throughout the world is filling, not a tomb, but the throbbing hearts and brains of those who love

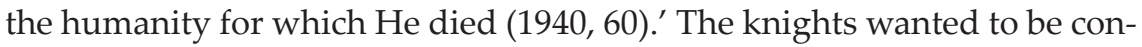
scientious workers and for their Christianity to be social and socialist. In the words of labour leader and historian George E. McNeill: 'The teachings of the carpenter's Son tend to counteract the bad influences of Mammon $(1887,468) . '$ Their attitude of chivalry is evident in their rituals. In the quotation below, taken from the secret ritual manual Adelphon Kruptos ('The Secret Brotherhood'), various officers question whether or not the initiate believes in God, whether s/he has a decent manual job, and is a compassionate human being:

A. U. K. Do you believe in God, the Creator and Universal Father of All? Candidate. I do.

A. U. K. Do you obey the Universal Ordinance of God, in gaining your bread by the sweat of your brow?

Candidate. I do.

A. U. K. Are you willing to take a solemn vow binding you to S. O. and M.A.?

6 The $\mathrm{K}$ of $\mathrm{L}$, not least its leadership, was imbued by a programmatic tolerant idealism. However, in the broader folk culture surrounding the brotherhood, other emotions could have an outlet - an example (Weir 1996,136) from a song: 'Half-crazed I wandered round the spot, and just beyond the town I met a dastard Pinkerton and struck the villain down; My brain was frenzied with the thought of children, friends, and wife I set my heel upon his throat and trampled out his life.' 


\begin{abstract}
Candidate. I am. [...]
W. A. (or M. W.) Repeat the Great Law of cPonXexirv [Knighthood].

V.S. I was an hungered, and ye gave me meat; I was thirsty, and ye gave me drink; naked, and ye clothed me; I was sick, and ye visited me; I was in prison, and ye came unto me. (Commons 1958, 30.)
\end{abstract}

Although the initiates are 'knights', they also call themselves 'tekton or 'architekton' ('Agenda. In Arcana', 15). This label is probably a legacy of freemasonry, but 'tekton' is originally the Koine Greek for the profession of Jesus's father, i.e. carpenter. God chose to live as a simple labourer. In contrast to the freemasons, who derive their origin from Hiram, the chief architect of Solomon's temple, the knights derive theirs from the God who descended to the human world to become a carpenter. In keeping with this heritage, the president of the $\mathrm{K}$ of $\mathrm{L}$ is, accordingly, called the Grand Master Workman (arche-tekton, or architect). Does this language of knights seem a little ridiculous, a little theatrical? Let us take a glimpse at the experience that lay behind the fraternity's foundation and struggle. This is how Terence V. Powderly, the Grand Master Worker who made the K of L one of the strongest labour organisations in American history, described his memory of witnessing a workplace accident at a mine in Avondale:

When on that September day at Avondale I saw the blackened, charred bodies of over one hundred men and boys as they were brought to the surface, when I saw a mother kneel in silent grief to hold the cold, still face of her boy to hers, and when I saw her fall lifeless on his dead body, I experienced a sensation that I have never forgotten. It was such a feeling as comes to me whenever I read of death in the mines or on the railroad.

Then when I listened to [union agitator] John Siney I could see Christ in his face and hear a new Sermon on the Mount. I there resolved to do my part, humble though it might be, to improve the condition of those who worked for a living (Powderly 1940, 35).

The sudden decline of the K of L - after the 1890s the fraternity was almost completely a thing of the past - has led historians, such as the acclaimed Marxist Eric Hobsbawm, to see the fraternity as an embarrassment, a rambling diversion, and a story of serious tactical error. In Primitive Rebels (1959) the symbolism, honorary titles, and rituals of earlier religious labour organisations appear to Hobsbawm as ridiculous and bizarre (1974, sp. chapter ix). In his attitude toward the world of fraternalism, socialist Christianity, 
and Christian Socialism, Hobsbawm is typical of the modern historians who dismiss religious narratives, rituals, and symbolism as irrational flaws. ${ }^{7}$

My brief description of the world of the K of L and the historiographical attitudes towards it aims to indicate several concerns. In the context of late nineteenth century American culture the seemingly bizarre symbolism and rituals of the $\mathrm{K}$ of $\mathrm{L}$ were in fact far from odd. Many ordinary workers saw fraternalism as a reasonable tool to improve a desperate situation. Thus, something that appears peculiar may be part of a bigger cultural movement, even if it is ignored by historians. This is hardly a new insight, but we should remind ourselves that, for example, esotericism used to be ignored by a more positivist generation of historians and was not taken seriously as a real historical force until the ground-breaking books by Frances Yates showed how esotericism was once a natural part of broader cultural fashions and ways of thinking. ${ }^{8}$

More notably, curiosity about what has been marginalised as 'rambling history' involves a basic methodological insight: the study of the strange, abnormal, and bizarre is quite often a way of showing the commonplace and general in a clearer light. This has been proven by Sigmund Freud's case studies of neurotic individuals, which taught us about normal human psychology, by the study of the Marquis de Sade by Max Horkheimer and Theodor W. Adorno, which highlighted features of the bourgeois mentality, and by Carlo Ginzburg's study of a miller by the name of Menocchio, which shows the boundaries of normal imagination and reasoning in Italy in the sixteenth century. In contrast to a history informed by social science's narrow interests in social formation and hegemony, humanistic research must also take into account the history of intellectual shortcomings, mistaken strategies, and bizarre symbolic action.

7 For the negative view of the K of L, se historians mentioned in Weir 1996,20n3, Gerteis 2007, 24 and Fink 1983, 18f. Ware $(1959,49)$ is also critical when it comes to the documents of the order: 'It got itself a gorgeous preamble and platform from the Industrial Congress, representing not present and future needs, but past hopes and disappointments.' Kaufman argues (2001, 555-60) that modern, 'secular' unions could 'better represent their interest by pursuing less ornate and more reasonable goals' (557f) and that without being 'committed to quasi-Masonic ritualism' (565). K of L was 'a victim' of fraternalism which had a 'perverse effect on' the labour movement.

8 In the preface to Charles Singer's classic A Short History of Science to the Nineteenth Century (1984 [1941]), historian Rolf Lindborg points out that it was typical of Singer's positivist generation to describe the progress of science and not 'all of the strange inconsistencies in natural research over the centuries'. The risk of reading history backwards is obvious. 


\section{Interpretation of signs and symbols}

In contrast to how the term is used in the evolutionary and cognitive sciences, in the humanities 'culture' should not be limited to achieved and handed-down (non-instinctive) knowledge. Rather, we need always to emphasise the proximity of culture to interpretation. The metal used in car production certainly has a history (a history related to the history of metallurgy, industry, and exploitation, as well as workers' daily work and life); but the physical metal is nevertheless not culture because it cannot be interpreted. The design, colour, and shape of the car on the other hand are open to interpretation. Had it not been for the invention of paper we would have had to do without books, but the paper in itself is not interpreted (even though the qualities of it might, for example, help us to situate it historically), unlike the lines on it that we call writing. The possibility and necessity for interpretation is thus the foundation for the definition of culture in society. In this sense animals do not have culture, even though different monkey groups teach their children to fish for ants in various ways.

The peculiarities of the $\mathrm{K}$ of $\mathrm{L}$ have nothing to do with the motives of the secret fraternity. ${ }^{9}$ We understand those well. The desire of the K of L for a decent life without hunger and worn-out bodies is not peculiar; what we find peculiar is their way of expression, their symbolism, aesthetics, and rhetoric. A study of the K of L must clearly involve study of their specific use of signs, symbols, and words. Let me give a further example from 'Adelphon Kruptos'. This ritual manual occupied a central position in the spiritual life of the Knights (Weir 1996, 49). ${ }^{10}$ All lodges used it as the basis of their ritual. Since the foundation of the fraternity in 1869 it seems only a few typed copies of Adelphon Kruptos were circulated, but some time after 1872 a limited number of copies were printed. Editions expanded after 1878, and after 1882 there was a compromise with the hostile Catholic Church, whereby a 'profaned' variant came into use (Weir 1996, 10, 28, 56, 240).

W. A. (or M. W.) Lift up your heads, O ye gates; even lift them up, ye everlasting doors, and the King of glory shall come in...

9 Engels writes in a letter to F.A. Sorge (29/11 1886) about 'confused principles and ludicrous organisation' of the $\mathrm{K}$ of $\mathrm{L}$.

10 The status of Adelphon Kruptos is evident, among other things, from the fact that the debates about changing it went so far that they ran the risk of splitting the $\mathrm{K}$ of $\mathrm{L}$ (Powderly 1890, 228 f) and that it was translated into, and printed in, French, German, Lithuanian and Polish (Powderly 1940, 66). 
Brothers. Who is this King of glory? The Lord of hosts, He is the King of glory. Selah.

\section{VOLUNTARY}

The W. A. (or M. W.) shall advance to the center, and facing the Capital shall say:

W A. (or M. W.) Behold the tabernacle of God is with men. (Rev. Xxi. 3.)

Response by all.

Brothers. And he will dwell with them, and they shall be his people, and God himself shall be with them, and be their God. (Rev. Xxi. 3.)

Choir and Brothers.

All. Amen.

The W. A. (or M. W.) shall draft or describe the NHWVE LWVD IM CPONXEXIIV [Great seal of Knighthood] at the center, and when done resume his station, give PXHWw HVFL [three raps], form the members of the new Assembly in a chain around the center (the other officers standing at their stations) and say:

W A. (or M. W.) Thus do I imprint the NHwve LwVD Im CPONXEXIIv [Great seal of Knighthood] on the center of the sanctuary, and thereby dedicate it to the service of God by Serving Humanity. Brothers, look well upon that Sacred Symbol of 'God and Humanity,' and indelibly imprint it upon your memory. Henceforth, while memory lasts, or ever this Globe performs its annual cycles in obedience to the Laws of the Universe, so shall ye perform your obligations. In obedience to the Laws of Universal Brotherhood.

Jubilate - Full Orchestra.(Commons 1957, 28. Ortography is simplified.)

As is well known, the importance of philology and language studies has been a key feature in the humanist project since the Renaissance, and was reinforced during the nineteenth century by the university system that was developed in line with the ideas of Wilhelm von Humboldt. Moreover, the perception of the significance of signs and language has considerably 
developed in the last hundred years or so: 'language shapes the world', according to Ludwig Wittgenstein, Ferdinand de Saussure, and their followers. The so-called 'linguistic turn' has come to mean that humanists are less interested in how 'the world shapes language'. I will give one example of this influence, again from Adelphon Kruptos.

In the symbolic world of the $\mathrm{K}$ of $\mathrm{L}$ handed-down Christian mythic images, esoteric symbolism from speculative freemasonry, and even emblematic traditions from the earlier modern era were woven together with the knights' experience of manual wage labour. An exegetical interpretation of the 'Great Seal of Knighthood' might illustrate this. The seal is a complex emblem of overlapping geometric symbols. It bears the motto 'That is the most perfect government in which an injury to one is the concern of all', traditionally attributed to Solon, and has a map of the Americas in its centre. (See Figure 1.)

In Powderly's interpretation of the geometric symbols an extra code is added to the established codes of interpretation, which, in the tradition of speculative freemasonry, involves interpreting symbols as philosophical/ theological abstractions such as Creation, Justice, Humanity, Wisdom, etc (1940, 65). This additional code gains its significance by reference to the material and physical dimension of human life. The triangle, for example, is interpreted as a symbol for production, distribution, and consumption, the pentagon as a symbol for the ideal of a five-day workweek, and the hexagon as a symbol for leverage tools, pulleys, wheels and axles, inclined planes, wedges, and screws. Thus, we witness how a 'workerist' class-centred line of decoding garnishes an older, guild-based, and esoteric tradition.

Another example from Adelphon Kruptos has, if the neologism is permitted, an ergogonic subject:

In the beginning God ordained that man should labor, not as a curse, but as a blessing; not as a punishment, but as a means of development, physically, mentally, morally, and has set thereunto his seal of approval, in the rich increase and reward. By labor is brought forth the kindly fruits of the earth in rich abundance for our sustenance and comfort; by labor, (not exhaustive) is promoted health of body and strength of mind; and labor garners the priceless stores of wisdom and knowledge. It is the 'Philosopher's Stone,' everything it touches turns to gold. 'Labor is noble and holy'. (from manuscript Adelphon Kruptos) 
The citation explains that work is 'the Philosopher's Stone', the 'substance' which, as in the tale of King Midas, turns to gold everything with which it comes in contact. Within the chemical tradition of alchemy it is said that 'the Philosopher's Stone' transforms matter into gold or, in the Rosicrucian tradition of alchemy, ennobles the soul. For hundreds of years alchemists have searched for the substance that will enable this transmutation to happen. The socialist play in Adelphon Kruptos with the codes of alchemy is cunning in its simplicity: 'The Philosopher's Stone', 'The Red Lion' is the work in itself. The magnum opus is the prima materia.

\section{The orectic}

In his 1970 work Sul materialismo the Italian philologist, Marxist, and critic of Freud's method of interpretation, Sebastiano Timpanaro, pioneered the questioning of structuralism and warned against the humanities' idealistic tendencies. Timpanaro held that there were inclinations that tended to identify something that is in many respects peculiar to humans, specifically the use of signs and language, as the essence of humanity. It is as if one were to say that the trunk is the essence of the elephant simply because it is typical of that species: 'to reduce man to what is specific about him with respect to other animals, is just as one-sided as to reduce him (as vulgar materialists do) to what he has in common with them $(1980,16)^{\prime}$.

Signs and language are of course essential when humanists interpret the human consciousness of life consciousness, but they should not be overestimated in terms of what is essential in human existence. That which is particular for humankind (the ability to symbolise our 'inner world' and our involvement in advanced communication) should not be identified with what is essential. For Timpanaro this is an argument in favour of a Marxist perspective, that is, the way to understand culture is by focusing initially on human need and the material conditions for satisfying them. The argument might be developed in a more sociological approach in studying the economic and social preconditions of culture and religion, or it might move towards a stronger focus on the sensual and corporeal aspects of human life. Here we will focus on the latter.

The humanities indeed entail the risk of a one-sided emphasis on the intellectual, conceptual, or cognitive dimension of human life at the expense of the sensual and corporeal. The rhetorical power of religious symbolism, whether in narrative or image, and their ability to persuade and inspire is not merely a matter of their intellectual content. Religious and ideological 
symbols are intimately connected with and refer to feelings, desires and bodily constitutions and processes. The scholarly tradition that has most forcefully highlighted this is psychoanalysis, which currently languishes as a discipline of the humanities. It has always been met with overwhelming scepticism by the discipline of the history of religions, often - undeniably - for good reasons. ${ }^{11}$ The emancipatory and critical goals of psychoanalysis, as well as its outlook on bodily signs as symptoms and subconscious desires, have been nurtured elsewhere, not least by the Frankfurt School. In studies by researchers such as Herbert Marcuse, Julia Kristeva, and Klaus Theweleit, the 'non-cognitivist' approach of psychoanalysis has indeed proven fruitful. ${ }^{12}$ The interest today's humanities has in corporality - and to a lesser degree in emotions and sensuality - is instead dominated by a onesided postmodern emphasis on 'the construction of' the body. Even if this tradition, founded by pioneers such as Michael Jackson and Judith Butler, once emerged out of materialistic praxis philosophy, it has since developed into a thoroughly idealistic understanding of culture.

The psychoanalytic movement has had very limited influence on the history of religions. It may be presumed to have had some bearing on a study many contemporary scholars of religions regard as a model for the interpretation of symbols, however: the anthropologist Victor Turner's classic analysis of the mudyi tree in The Forest of Symbols: Aspects of the Ndembu Ritual (1967). ${ }^{13}$ According to Turner, the symbolism of the Ndembu people encompasses an opposition between, on the one hand, an ideological or normative dimension and, on the other, a sensory or 'orectic' dimension. What this means is that Ndembu symbols refer to social laws and morality and at the same time to the individual's sensuality and corporeality, and create a nexus between these two dimensions. I will give an example of the simultaneous ideological and orectic dimension from Adelphon Kruptos in which an initiation ritual is prescribed:

The U. K. [Unknown Knight] places the candidate and the friends at the center: places their left hands on the Sacred Scriptures, fingers over, thumb under: directs the candidate to grasp the * of his friend, the friend that of the

11 Alfred L. Kroeber's devastating criticism of Totem und Tabu was already published in 1920 (re-printed in Lessa \& Vogt 1979).

12 I am thinking of general approaches such as Marcuse's Eros and Civilisation (1955), empirical studies such as Klaus Theweleit's Männerphantasien $(1977,1978)$ and innovative concepts such as Julia Kristeva's distinction between 'the symbolic' and 'the semiotic'.

13 For Freud's unacknowledged influence on Turner, see Oring 2009. 
U. K., and the U. K. takes that of the candidate, the three forming a triangle over and around the Altar, and all pronounce the Vow. (Adelphon Kruptos.)

When I first read this passage I was puzzled. I had previously understood that the authors of the manual replaced the name of the fraternity with nine asterisks, but in this passage it seemed that an asterisk had replaced an everyday word. In a later version it had been 'profaned' so as to pacify criticism from the Roman Catholic Church; likewise in a French version this passage is replaced by the straightforward 'place the left hand on the heart and raise the right hand'(Knights of Labor Illustrated, 10), respectively 'lui fait lever la main droite et placer la main gauche sur le coeur' (Adelphon Kruptos, French version, 8.). This suggests that '*' should be read as 'heart'. However, the English verb 'grasp' in the quotation seems to disqualify this interpretation. You cannot 'grasp something' if your hand is placed on your heart (chest). Some other decryption is therefore needed.

Elsewhere in the text we can see that ${ }^{\prime * \prime}$ replaces important key terms such as 'Knight', 'Knighthood', and 'Labor'. Similarly, it is used when the Knights wish to avoid printing secret signs and passwords. In connection with the mention of a secret handshake we come closer to solving what ${ }^{\prime * \prime}$ signifies in our quotation. In the older, 'sacral' version of Adelphon Kruptos we find the following description and comment: 'As the * distinguishes man from all other orders of creation, and by it alone man is able to achieve wonders of art and perform labor; we always, therefore, approach a brother in this way, and by so doing, recognize the wisdom of the Great Master.'(Adelphon kruptos, 19.) What the Knights grasp during the solemn initiation ceremony when new members are sworn into the brother- and sisterhood of the order, is thus the thumb. The thumb, which, according to the comment, is unique to humans and has made it possible for human beings, through work, craft, and art, to hold a unique position in creation. It seems to me a worthy 'orectic' reference for a group consisting of manual (from Latin manus, 'hand') workers. Having decoded the thumb, I became aware of the symbolic significance of the hand: for example, the recurring mention of 'clean hands'. I suppose this symbolism should not have surprised me, but until this point I had failed to spot it. Prior to this discovery I had not even reflected upon the fact that the K of L's most frequently used motto, S.O.M.A., which stands for 'Secrecy, Obedience, and Mutual Assistance', is obviously an allusion to the Greek word soma, ' body'.

Why has it been difficult for historians of religions to take the orectic referent of symbolism into account? Perhaps it is because previous analy- 
sis of symbolism and religious discourse has been based too much on familiarity with secular ideologies. These generally present themselves as reasonable discourses informed by intelligent ideas - discourses that, nota bene, exclude straightforward solutions of health and existential problems. Liberalism, as the prime example here, offers the prospect of political and economic freedom, but does not have a cure for cancer, nor does it offer a vindication for the death of a dear sibling. The vigour of religions consists, however- and this is quite possibly also true of, to use John E. Smith's (1994) expression, 'quasi-religious' ideologies such as fascism - in the ability to merge the overall political issues of power and social order with the concrete existential and health-and body-related experiences, and thus to intertwine the ideological with the orectic.

In complex and chaotic material details enable us to see deeper connections. In his famous article 'Clues: roots of an evidential paradigm' (1989), historian Carlo Ginzburg compares three paths of knowledge from the late nineteenth century. Based on descriptions of Conan Doyle's Sherlock Holmes, Giovanni Morelli's method for the identification of art forgery, and Sigmund Freud's psychoanalytic writings Ginzburg argues for the existence of a specific 'code-deciphering paradigm'. Ginzburg suggests that this scholarly paradigm is characterised by a hermeneutical focus on 'privileged zones' $(1989,123)$. For the detective it involves locating and identifying clues to catch criminals. For the psychoanalyst it involves being alert to unconscious symptoms and dream symbolism to lay bare the structure of the patient's desires. For the art connoisseur who wants to identify the artist behind a painting it involves studying unconsciously but habitually painted details - and not to concentrate on, for example, conscious choices of motif. The methodological interest in detail - such as "*' for 'thumb' - is yet another feature that distinguishes the humanities from the social sciences.

\section{The utopian dimension}

The founders of sociology (Marx, Durkheim, Weber) primarily understood religion as an ideological discourse (see e.g. Turner 1994). Ideology was perceived as attitudes, values, and convictions that mobilised forces to consolidate and legitimise the social status of certain groups in a given society. The culture of the $\mathrm{K}$ of $\mathrm{L}$ contained ideological elements in this sense, among others in the form of myths, which, as Bruce Lincoln has suggested, can be seen as 'ideology in narrative form' $(1999,147)$. Here is an example from Adelphon Kruptos: 
In the beginning the great Architect formed the Universe; The governing principle of which is Immutable Justice. In its Beautiful proportions is displayed Omniscient Wisdom; And sealed His work with the signet of Everlasting Truth; Teaching, that everything of value, or merit, is the result of creative Industry; And the cooperation of its harmonious parts evermore inculcates perfect Economy (Agenda: In arcana).

In myths - as in this fragment - the task is not only, as in secular, political ideologies, to make attitudes, values, and convictions appear natural, evident, and irrefutable; it is bolder still. Attitudes, values, and convictions should be seen as elements of a divine order. It is not only wage-earners, the quotation suggests, who long for justice and cooperation, and who believe that strenuous work is the true basis of economic value. It is God who has arranged it like this.

For the heirs of Marx, Durkheim, and Weber within the history of religions it is often assumed that the privileged discourse of the elite is ideological, while protest movements and movements of resistance, particularly millenarian movements, are utopian. ${ }^{14}$ As a protest movement against the hegemony of 'the kings of capital' the world of the Knights of Labor ought thus to show a glimmer of utopian illumination. And such is the case. Here is an example from one of their songs:

\author{
Work, Brothers mine; \\ work, hand and brain; \\ We'll win the Golden Age again; \\ And Love's Millennial morn shall rise \\ In happy hearts and blessed eyes. \\ Hurrah! Hurrah! \\ True Knights are we \\ In Labor's lordlier chivalry (Weir 1996, 110).
}

The utopia of the K of $\mathrm{L}$ was a world of work liberated from brutal coercion. It is the dream of work where labour is meaningful and where the fruits of it belong to those who conduct it. They do not dream about le droit à la paresse, 'the right to be lazy', to use the title of a book published in 1883 by the French socialist Paul Lafargue, which, by the way, was one of the most popular books among workers around the turn of the century.

14 For a somewhat longer discussion of this, see Arvidsson 2013. 
Let us take a step back, however. The constellation that the upper classes relate to the lower classes as ideology relates to utopia is not self-evident. Sociologist Karl Mannheim, philosopher Ernst Bloch, and contemporary literary theorist Frederic Jameson argue for a somewhat different case. ${ }^{15}$ According to Jameson the interpreter of a work of art or discourse might use two distinctive pairs of hermeneutical spectacles (1981, 291f et passim). 'Negative hermeneutics' pays attention to the 'instrumentality' of an artefact, that is, to how it intervenes in ongoing social and political conflicts. 'Positive hermeneutics', by contrast, look for the utopian dimension. In the same artefact-Jameson is speaking here primarily about modern literature -ideological and utopian elements appear intertwined, involving the entanglement of two distinct sensory modes and modes of time consciousness: on the one hand the consolidation, stabilisation, support, and mobilisation of ideology, on the other the anticipation, dreaming, demanding, and openheartedness of utopia. It is therefore methodologically essential not only to reveal the ideological-instrumental aspects of utopias, but also to search for the utopian aspects of evidently ideological narratives.

The $\mathrm{K}$ of $\mathrm{L}$ was part of the widespread interest in fraternalism during America's Gilded Age. At its core lay ideological aspirations. Fraternalism strengthened and supported a sense of community. But it was at the same time designed to bring about a utopian imagination, and even to provide the seed for the fulfilment of this utopia. In the manifesto, texts, and activities of the $\mathrm{K}$ of $\mathrm{L}$ we thus find an intertwining of ideology and utopianism. One moment the struggle involves the battle for 'bread and butter' and the fight for union-friendly labels on commodities, and the next it involves the millenarian fight for 'the Commune of Christ' (Halker 1991, 268), a term which alludes both to the most fundamental ritual of the Christian community, the communion, and the Paris Commune, the world's first socialist experiment. A photograph taken at the National General Assembly in Richmond in 1886 may illustrate the fusion. (See Figure 2.) We can examine the photograph for ideological signs, i.e. the traits of what today would be called empowerment. The women form their own influential group within the order. They are properly dressed and display no bohemian manners. The oldest woman is naturally seated in the centre of the photograph. At the same time the picture is utopian in the sense that it depicts women as full delegates in a universal brotherhood (fraternité). Moreover, they have

15 For utopian or, to use Fredric Jameson's terminology (2010, 434), 'utopological' themes within Marxism, see Geoghegan 2008. 
brought a baby with them. The unwritten future knows no better symbol. ${ }^{16}$ Politologist Vincent Geoghegan $(2008,16)$ believes that it is typical that 'a utopia asks the most awkward, the most embarrassing questions', and the presence of the baby in the solemn assembly precisely does this.

The actual changes in culture through the centuries raise questions about human nature and history. They also raise questions about matters never realised: dreams, utopias, hopes, and longings are indeed objects for humanistic inquiry. Ideas that never materialised, or that were realised but soon thwarted, or ideas that barely influenced the course of history at all are all important for the humanistic interest in knowledge. These dreams and ideas were by their nature embedded in social contexts, and in many ways they mirrored the shortcomings that existed in society at a given moment. But, as with art, at the same time they imply something beyond social reproduction. From the renaissance humanist Giovanni Pico della Mirandola to Jean-Paul Sartre and Ernst Bloch, human nature has been described as the free capacity to envision the non-existent: man is the Being that brings Nothing into the world. This fundamental insight opens up the relevance of the study of marginal phenomena as well as yet to be realised fantasies for the humanities.

\section{Empathy}

The baby in the photograph brings us to the last theme I wish to address concerning the humanistic study of religions: questions regarding the usefulness for humanistic exploration of empathy, and information about subjective intentions and meanings. These questions are among the most controversial in the humanities because they smack of arbitrariness, speculation, and misdirected benevolence towards religious and cultural phenomena. Like nearly everyone, I am confident in the methodological advantages of the natural sciences and I am not a stranger to the ideal of a unity of science (Einheitswissenschaft). I believe that scholars of the humanities cannot, in a phenomenological fashion, place the statements of the alleged effects of magical powers or divine intervention 'in brackets' when scientists have refuted these hypotheses. At the same time I have no doubt that human history and culture constitute a qualitative leap - a leap that blocks reductionist biologism. Alongside all long-established arguments

16 Compare expressions such as 'the society was pregnant with', which Frederic Jameson has made some remarks about in Valences of the dialectic (2010) in connection with a discussion on socialist utopianism. 
against this kind of reductionism, anthropologist Marshall Sahlins recently highlighted the fact that culture (defined broadly as acquired, as opposed to instinctual, behaviours) is thousands of years older than the birth of anatomically modern man: 'Culture is older than Homo sapiens $(2008,104) .{ }^{17}$ This means that humankind has from the outset been determined by culture and that, consequently, culture is human nature: 'The critical point is that for some three million years humans evolved biologically under cultural selection. We have been fashioned body and soul for a cultural existence $(2008,104) .{ }^{\prime 18}$ Notwithstanding how Sahlins's argument will be received, the earlier critiques of biologism (from neo-Kantians via phenomenology, critical theory, and hermeneutics to social constructivism) stand. The devastating critique of biologism should not, however, be seen as carte blanche for methodological sloppiness, personal opinions, and unfounded speculations. For how can we really be sure if the method of the humanities is based partly on empathy and methodological identification with the human objects under investigation?

A tool for knowledge empathy requires, as Hans-Georg Gadamer has emphasised, a human-specific historical community (2010, 296-311, 352-367). When scholars study different persons through history and across cultures they inevitably discover similarities between their own attitudes, values, and convictions and those of the people they are studying. If they do not discover these similarities, they have simply failed to accumulate any real knowledge. They have not dug deeply enough. No real understanding has taken place - a die-hard hermeneutic scholar would argue - as long as the difference between people as a subject of knowledge and as an object of knowledge is insurmountable. This claim surely places great demands on the scholar. It requires advanced studies in history, language, and culture, as no individual can turn every single experience we have into something very useful, namely the cumulated corpuses of humanistic literature. We should also consult art, literature, and other forms of expression. Real knowledge of our fellow human beings, as opposed to, for example, statistics, means that, with the help of our ability to feel empathy, we can approach 'their

17 It comes as no surprise that the question of whether we can accept the claim that culture is older than the anatomically modern human involves the definition of culture. Sahlin leans towards Richard G. Klein's research, which means, if I understand it correctly, that culture is defined as 'information acquired from conspecifics through learning or imitation' (Klein 2008). 18 It is thought-provoking to contrast this claim with - or is it rather to develop a parallel? cultural theorist Terry Eagleton's assertion that culture cannot be said to be true human nature, but is a addition to nature: 'It is not that culture is our nature, but that it is of our nature, which makes our life difficult.' (2000, 99.) 
truth', that is, their basic needs and longings. None of this is different just because we study people who harbour anti-humanistic beliefs, for example, ancient Gnostics or antiziganist Europeans. We still have to approach their 'truth' (for example, their struggle for integrity and dignity in a chaotically changing world). To note similarities and recognise human traits involves, as historian of ideas Quentin Skinner has reminded us, understanding the intent behind any given cultural expression (see discussions in Skinner 1988).

The German philosopher Jürgen Habermas has famously argued that there are three 'knowledge interests' (Erkenntnisinteresse) within science. Apart from the technical and practical knowledge interests, in Knowledge and Human Interests (1978) Habermas argues for the existence of an emancipatory knowledge interest. The prime example of this knowledge interest is psychoanalysis. Habermas's exploration has been influential, even if not within the history of religions. For my taste, however, the term 'emancipatory' sounds a little too idealistic, or akin to self-help books. Instead, I believe it is better to describe the knowledge interest behind the humanities as something like the aim to help people create a culture that makes them feel 'at home in the world'. The metaphor surrounding 'home', examined by among others the anthropologist Michael Jackson (1995, see also Berger, Berger \& Kellner 1974), seems to me to be closer to the heart of the humanities: to study human history is to study instinctive feelings of belonging and feelings of its opposite, alienation.

Thus, my position involves a methodical search for the forces that have conducted what the historian Carlo Ginzburg describes as 'taking note of a historical mutilation of which, in a certain sense, we ourselves are the victims' (2013, xxvi). The humanistic study of religions must uncover the forces that have made the dreams of feeling at home in the world go unfulfilled for most of the people who have walked the earth over the past three thousand years. ${ }^{19}$ This does not involve chasing villains. Humanists are neither policemen nor prosecutors. However, if history did not contain villains, if all suffering was natural (as Nietzsche would have it), what need would there be for historical knowledge? In contrast to postmodernists, with their focus on various hidden agendas behind the search for knowledge, I am not averse to the idea that people at least sometimes study history for the same reason they play with their dogs or bake a cake: because it is fun

19 In the daring Sedna oder Die Liebe zum Leben (1984) anthropologist Hans Peter Duerr dates alienation and the rise of ideologues that deny life all value ('the ideology of escapism') or stimulate a longing for an afterlife ('transcendence ideology') to the beginning of the first millennium B.C. 
and enjoyable. Not all searches for knowledge are a manifestation of a 'will to power'. But academic historiography must, nevertheless, be more than a pastime or a kind of elevated meditation on human nature and destiny. Historiography- and this is where such diverse philosophers of history as Friedrich Nietzsche and Walter Benjamin meet - should be conducted to fill us with awe, to make us proud or angry (Nietzsche 1980; Benjamin 1974, 691-706). We must therefore look for the forces that have generated alienation.

The search for alienating, anti-humanist forces is not a search for individual villains, but for structural errors. As has already been said, humanists are neither policemen nor prosecutors; and nor are they sensationalist reporters. It is more important to highlight slow hopeless suffering than the spectacular. ${ }^{20}$ In the working class poetry that developed around the $\mathrm{K}$ of $\mathrm{L}$, we quite frequently find this particular assessment of the importance of focusing on this everyday, almost invisible, suffering:

In a dim-lighted chamber a dying maiden lay,

The tide of her pulses was ebbing fast away;

In the flush of her youth she was worn with toil and care

And starvation showed its traces on the features once so fair.

No more the work-bell calls the weary one.

Rest, tired wage-slave, in your grave unknown;

Your feet will no more tread life's thorny, rugged way,

They've murdered you by inches upon thirty cents a day (Weir 1996, 124)!

20 The American writer Mark Twain expresses this attitude in a fiery passage in A Connecticut Yankee in King Arthur's Court (1889, 157.): 'Why, it was like reading about France and the French, before the ever memorable and blessed Revolution, which swept a thousand years of such villainy away in one swift tidal-wave of blood - one: a settlement of that hoary debt in the proportion of half a drop of blood for each hogshead of it that had been pressed by slow tortures out of that people in the weary stretch of ten centuries of wrong and shame and misery the like of which was not to be mated but in hell. There were two 'Reigns of Terror', if we would but remember it and consider it; the one wrought murder in hot passion, the other in heartless cold blood; the one lasted mere months, the other had lasted a thousand years; the one inflicted death upon ten thousand persons, the other upon a hundred millions; but our shudders are all for the 'horrors' of the minor Terror, the momentary Terror, so to speak; whereas, what is the horror of swift death by the axe, compared with lifelong death from hunger, cold, insult, cruelty, and heart-break? What is swift death by lightning compared with death by slow fire at the stake? A city cemetery could contain the coffins filled by that brief Terror which we have all been so diligently taught to shiver at and mourn over; but all France could hardly contain the coffins filled by that older and real Terror - that unspeakably bitter and awful Terror which none of us has been taught to see in its vastness or pity as it deserves.' 
And Walter Benjamin wrote the following justly famous and memorable lines, which are also inscribed on the memorial stone at his grave:

'It is a more difficult task to honour the memory of the nameless than the famous. Historiography is dedicated to the memory of the nameless. ${ }^{21}$

Scholarly disciplines are ultimately defined, I would argue, by a given situation of query. The query situation of archaeology, for example, is often made up of concrete, material remains: 'What is this?!' I would like to suggest that the query situation for the humanistic study of religions should be described as the feeling of surprise at what Karl Marx, in a famous passage in the introduction to Zur Kritik der Hegelschen Rechtsphilosophie, called the 'imaginary flowers [that sprout] on the chain' (die imaginären Blumen an der Kette; 1964, 379). It is the sense of surprise at the existence of religious and quasi-religious fantasies and accompanying ceremonies and institutions that seems to be designed to ease the sense of homelessness in the world that has been widely felt by the overwhelming majority of the world's population for, if we have interpreted the signs correctly, at least three thousand years. I understand the history of religions to be a core discipline within the humanities, not only because almost all culture throughout history has been religious culture, but because the discipline focuses not only on what has been realised through history, but also on fantasies - fantasies born out of real needs, out of feelings of vulnerability and anticipation.

Stefan Arvidsson is Professor in the History of Religions at the School of Cultural Sciences, Linnæus university, Sweden. E-mail: stefan.arvidsson@lnus.se

21 'Schwerer ist es, das Gedächtnis der Namenlosen zu ehren als das der Berühmten. Dem Gedächtnis der Namenlosen ist die historische Konstruktion geweiht (Benjamin 1974,1241).' For an argument in the same spirit, see Hobsbawm 1999,12. 
Bibliography

Primary sources

Adelphon Kruptos

Typewritten version that, according to the handwriting on the cover page, belonged to Terence V. Powderly. The original can be found in 'The Papers of Terence V. Powderly' at Catholic University (Washington, D.C.). Copy in the author's possession. Incomplete digitized version on Catholic University of America <http://cuomeka.wrlc.org/ exhibits/show/knights/kol-docs/kol-doc-2>, accessed 18 Mars 2015.

Adelphon Kruptos. Cette publication renferme les règles qui gouvernent les séances des Chevaliers du travail au Canada.

1886 French translation of Knights of Labor illustrated. Digitized on <http:// openlibrary.org/books/OL24636670M/Adelphon_Kruptos>, accessed 14 April 2015.

Agenda. In arcana

Handwritten and commented text in notepad, probably from 1869. Author is presumably Uriah Smith Stephens. Original can be found in 'The Papers of Terence V. Powderly' at Catholic University (Washington, D.C.). Copy in author's possession.

Commons, John R. (ed.)

1958 A documentary history of American industrial society. Vol. 10, Labor movement: [1860-1880], New York.

Knights of Labor illustrated: 'Adelphon kruptos,' the full, illustrated ritual including the 'Unwritten work' and an historical sketch of the order

1886 Chicago, Ezra A. Cook, 1886. From collections at International Institute of Social History, Amsterdam.

Record of proceedings of the General Assembly of the $* * * * * * * *$ held at Reading 1878 Internet Archive <http://www.archive.org/details/RecordOfProceedingsOfTheGeneralAssemblyOfTheKnightsOfLabor $>$, accessed 14 April 2015.

\section{Powderly, Terence V.}

1940 The Path I Trod. The Autobiography of Terence V. Powderly. Editd by Harry J. Carman, Henry David och Paul N. Guthire. New York. Columbia University Press 


\section{Literature}

\section{Arvidsson, Stefan}

2013 Review of Gods and Demons, Priests and Scholars: Critical Explorations in the History of Religions (Bruce Lincoln, 2012) - Method \& Theory in the Study of Religion 25 (1), 168-77, 213.

\section{Barnekow, Sten}

2003 Erfarenheter av zen. Dissertation. Lunds universitet: Nya Doxa.

\section{Belfiore, Eleonora \& Anna Upchurch (eds)}

2013 Humanities in the twenty-first century: beyond utility and markets. Basingstoke : Palgrave Macmillan

\section{Benjamin, Walter}

1974 Gesammelte Schriften. Bd 1. Frankfurt am Main: Suhrkamp.

\section{Berger, Peter L., Brigitte Berger \& Hansfried Kellner}

1974 The Homeless Mind: Modernization and Consciousness. New York: Vintage Books.

\section{Dawson, Lorne L.}

1988 Reason, Freedom, and Religion: Closing the Gap between the Humanistic and Scientific Study of Religion. New York: Lang.

\section{Duerr, Hans Peter}

1984 Sedna oder Die Liebe zum Leben. Frankfurt am Main: Suhrkamp.

Durkheim, Émile

2006 (1897) On suicide. Translated by Robin Buss. London: Penguin

\section{Eagleton, Terry}

2000 The Idea of Culture. Oxford: Blackwell.

\section{Ekström, Anders \& Sverker Sörlin}

2012 Alltings mått: humanistisk kunskap i framtidens samhälle. Stockholm: Norstedt.

Engels, Frederick

1886 Letter to F.A. Sorge 29/11. - Marxist Internet Archive. <https://www. marxists.org/archive/marx/works/1886/letters/86_11_29.htm>, accessed 16 April 2015.

\section{Fink, Leon}

1983 Workingmen's democracy: the Knights of Labor and American politics. Urbana: University of Illinois Press.

Forser, Tomas \& Thomas Karlsohn (eds)

2013 Till vilken nytta? En bok om humanioras möjligheter. Göteborg: Daidalos. 


\section{Gadamer, Hans-Georg}

2010 Hermeneutik. 1, Wahrheit und Methode: Grundzüge einer philosophischen Hermeneutik. 7th edition. Tübingen: Mohr Siebeck.

\section{Geoghegan, Vincent}

2008 Utopianism and Marxism. London: Methuen.

\section{Gerteis, Joseph}

2007 Class and color line. Interracial class coalition and the Knight of Labor and the Populist Movement. Durham. Duke University Press.

\section{Ginzburg, Carlo}

2013 The cheese and the worms: the cosmos of a sixteenth-century miller. Translated by John and Anne C. Tedeschi. Baltimore: Johns Hopkins University Press.

1989 Clues, myths, and the historical method. Translated by John and Anne C. Tedeschi. New York: Palgrave Macmillan.

\section{Habermas, Jürgen}

1978 Knowledge and Human Interests. 2nd edition. London: Heinemann

\section{Halker, Clark}

1991 Jesus was a carpenter. Labor song-poets, labor protest, and true religion in gilded age America. - Labor History, 32 (2): 273-289.

\section{Hobsbawm, Eric J.}

1974 [1959] Primitive Rebels: Studies in Archaic Forms of Social Movement in the 19th and 20th Centuries. Manchester: Manchester University Press.

1999 On history. London: Abacus.

\section{Holbrook, Clyde Amos}

1963 Religion, a Humanistic Field. Englewood Cliffs: Prentice-Hall.

\section{Jackson, Michael}

1995 At Home in the World. Durham: Duke University Press.

\section{Jameson, Fredric}

1981 The political unconscious: narrative as a socially symbolic act. Ithaca, N.Y.: Cornell U.P.

2010 Valences of the Dialectic. London: Verso.

\section{Kaufman, Jason}

2001 Rise and Fall of a Nation of Joiners: The Knights of Labor Revisited, Journal of Interdisciplinary History 31 (4), 553-579.

\section{Klein, Richard G.}

2009 Culture, population structure, and low genetic diversity in Pleistocene hominins. Proceedings of the National Academy of Sciences of the United States of America, 106 (1), 33-37. [or 2008?] 


\section{Lessa, William A. \& Evon Z. Vogt (eds)}

1979 Reader in Comparative Religion: an Anthropological Approach. 4th edition. New York: Harper \& Row.

\section{Lincoln, Bruce}

1999 Theorizing Myth: Narrative, Ideology, and Scholarship. Chicago, Ill.: University of Chicago Press.

\section{Lindborg, Rolf}

1984 Introduction - Charles Singer, Naturvetenskapens historia. Lund: LiberLäromedel.

\section{Marcuse, Herbert}

1955 Eros and civilization: a philosophical inquiry into Freud. New York: Vintage.

\section{McCutcheon, Russell T.}

2006 'It's a Lie. There's No Truth in It! It's a Sin!': On the Limits of the Humanistic Study of Religion and the Costs of Saving Others from Themselves. - Journal of the American Academy of Religion, 74 (3), 720-750.

\section{McNeill, George E. et al.}

1887 History of the Knights of Labor. Written with help from with Cook, William, J. M. Hilsee, R. W. Keen, J. S. Kennedy, R. C. Macauley \& James L. Wright. - McNeill, George E. (ed.) The Labor movement. Chapter Boston: A. M. Bridgman

\section{Moi, Toril}

2006 Henrik Ibsen and the birth of modernism: art, theatre, philosophy. Oxford: Oxford University Press.

\section{Nietzsche, Friedrich}

1980 On the Advantage and Disadvantage of History for Life. Indianapolis: Hackett Publishing Company.

\section{Nordin, Svante}

2008 Humaniora i Sverige: framväxt, guldålder, kris. Stockholm: Atlantis.

\section{Nussbaum, Martha Craven}

2010 Not for profit: why democracy needs the humanities. Princeton, N.J.: Princeton University Press.

\section{Oring, Elliot}

1993 Victor Turner, Sigmund Freud, and the return of the Repressed. Ethos, 21 (3), 273-294. 


\section{Persson, Mats}

1994 Förnuftskampen: Vitalis Norström och idealismens kris. Stockholm: B. Östlings bokförl. Symposion.

\section{Phelan, Craig}

2000 Grand Master Workman: Terence Powderly and the Knights of Labor. Westport, Conn.: Greenwood Press.

Powderly, Terence V.

1890 Thirty Years of Labor. 1859-1889. Columbus: Excelsior.

\section{Sahlins, Marshall David}

2008 The Western Illusion of Human Nature: With Reflections on the Long History of Hierarchy, Equality and the Sublimation of Anarchy in the West, and Comparative Notes on Other Conceptions of the Human Condition. Chicago, Ill.: Prickly Paradigm.

\section{Sartre, Jean-Paul}

1976 Critique of dialectical reason. 1, Theory of practical ensembles. London: NLB.

\section{Skinner, Quentin}

1988 Meaning and Context: Quentin Skinner and his Critics. Cambridge: Polity.

\section{Small, Helen}

2013 The value of the humanities. Oxford: Oxford University Press.

\section{Smith, John E.}

1994 Quasi-religions: Humanism, Marxism and Nationalism. Basingstoke: Macmillian.

\section{Theweleit, Klaus}

1977-1978 Männerphantasien. Frankfurt am Main: Roter Stern.

\section{Timpanaro, Sebastiano}

1980 On materialism. London: Verso. [1970?]

\section{Turner, Bryan S.}

1994 Religion and Social Theory. London: Sage.

\section{Turner, Victor W.}

1967 The forest of symbols: aspects of Ndembu ritual. Ithaca, N.Y.: Cornell University press.

\section{Twain, Mark}

1889 A Connecticut yankee in king Arthur's court. New York \& London: Chatto \& Windus. 


\section{Ware, Norman J.}

1929 The Labor Movement in the United States 1860-1895. A Study in Democracy. New York and London: D. Appleton and Company.

Weir, Robert E.

1996 Beyond labor's veil: the culture of the Knights of Labor. University Park: Pennsylvania State University Press.

Windelband, Wilhelm

1907 Präludien. Tubingen: Mohr Verlag. 


\section{Appendix.}

Figure 1. The Great Seal of Knighthood, symbol of the K of L. Reprinted from Powderly 1940, 440.

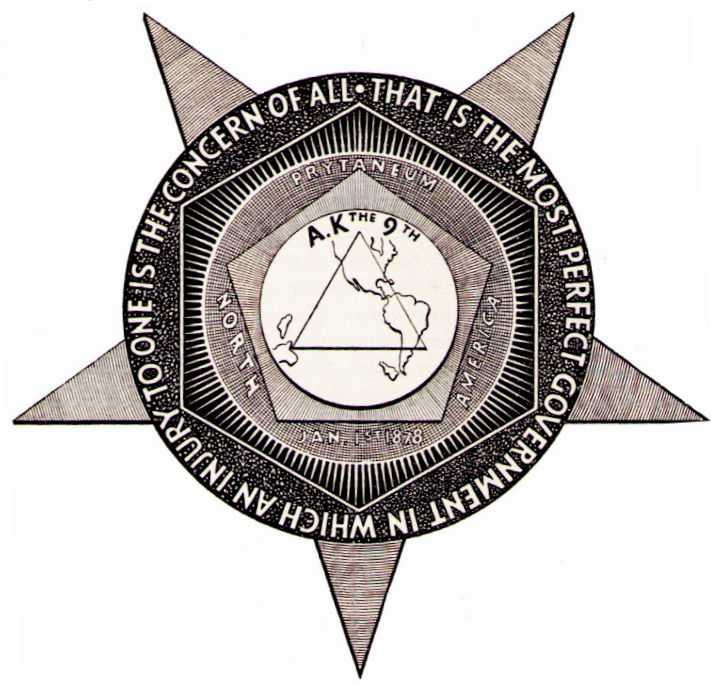

Figure 2. Delegates to the National General Assembly in Richmond in 1886. Photograph by Terence V. Powderly from Terence Vincent Powderly Photographic Collections, The Catholic University of America.

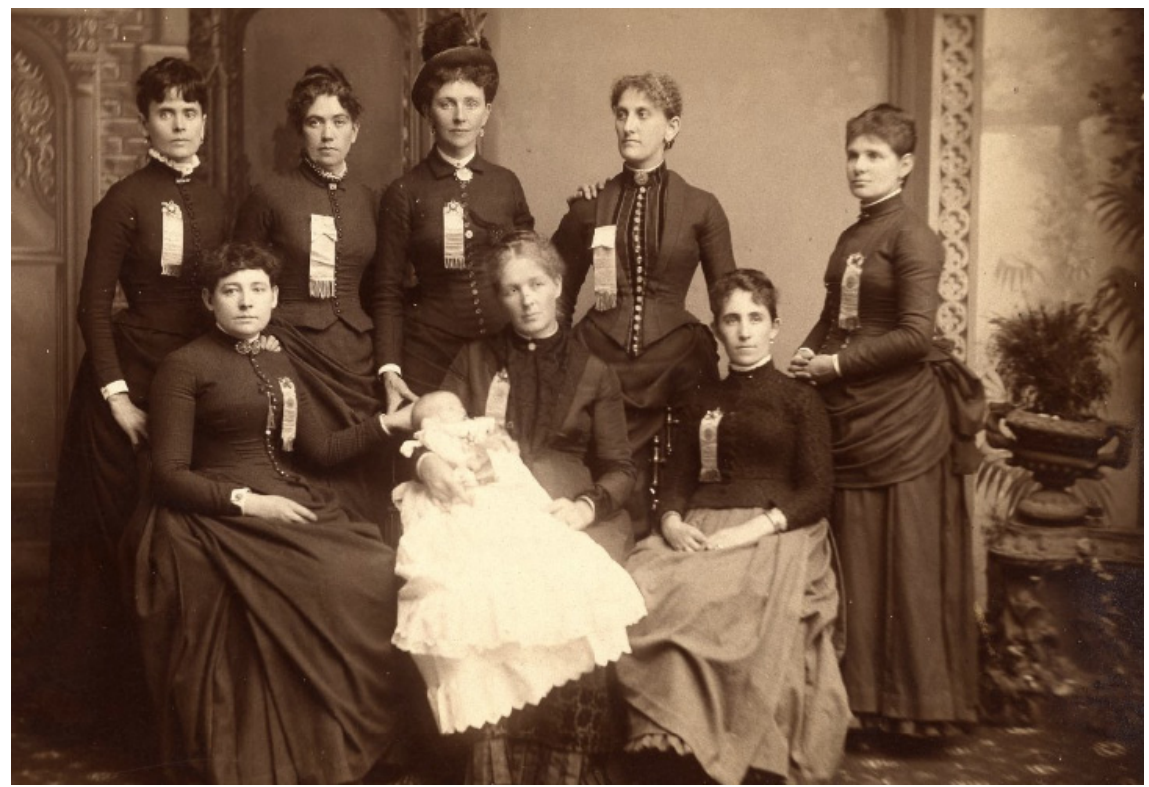

